\title{
Improvement of Tourette syndrome symptoms with penicillin prophylaxis in two male children presenting with severe functional disorder
}

\author{
Ağır işlevsel bozukluk ile başvuran iki erkek çocukta Tourette sendromu \\ belirtilerinin penisilin profilaksisi ile iyileşmesi
}

\author{
Serhat Kala ${ }^{1}$ D, Mahmut Zabit Kara² ${ }^{\mathbb{D}}$, Mehmet Hamdi Örüm ${ }^{\mathbb{D}}$ \\ ${ }^{1}$ Child and Adolescent Psychiatry, Private Clinic, Mersin, Turkey \\ ${ }^{2}$ Department of Child and Adolescent Psychiatry, University of Health Sciences, Antalya Training and Research Hospital, Antalya, Turkey \\ ${ }^{3}$ Department of Mental Health and Diseases, Kahta State Hospital, Adiyaman, Turkey
}

\begin{abstract}
PANDAS (Pediatric autoimmune neuropsychiatric disorders associated with streptococcal infections) is a term that refers to episodic prepubertal and sudden onset movement disorders and/or obsessive-compulsive symptoms associated with streptococcal infection. It is suggested that the autoimmune process initiated by the infection affects the basal ganglia and causes neuropsychiatric symptoms. It is thought that in these cases with neuropsychiatric symptoms, penicillin prophylaxis may be useful. In this article, the effects of penicillin prophylaxis in two male patients with Tourette syndrome associated with streptococcal infection are discussed.

Keywords: PANDAS, penicillin, streptococcus, Tourette syndrome.
\end{abstract}

öz

PANDAS (Streptokok enfeksiyonları ile ilişkili pediatrik otoimmün nöropsikiyatrik bozukluklar), streptokok enfeksiyonu ile ilişkili epizodik seyirli prepubertal ve ani başlangıçlı hareket bozukluklarını veya obsesif-kompülsif semptomları ifade eden bir terimdir. Bu hastalarda enfeksiyon tarafından başlatılan otoimmün sürecin bazal gangliyonları etkilediği ve nöropsikiyatrik belirtilere neden olduğu öne sürülmektedir. Nöropsikiyatrik belirtileri olan bu olgularda penisilin profilaksisinin faydalı olabileceği düşünülmektedir. Bu yazıda streptokok enfeksiyonu ile ilişkili Tourette sendromu belirtileri ortaya çıkan iki erkek olguda penisilin profilaksisinin etkisi tartışılmıştır.

Anahtar sözcükler: PANDAS, penisilin, streptokok, Tourette sendromu.

The burden of psychiatric disease is increasing all over the world. ${ }^{[1-5]}$ While a portion of admissions are at emergency departments, a large majority occur in outpatient clinics. ${ }^{[6,7]}$ In these admissions, which may be secondary instead of primary psychiatric symptoms, it may be difficult to rule out organic causes in some cases. ${ }^{[5]}$ In the last few decades, the set of neuropsychiatric symptoms characterized by obsession and tics due to immunologic response following Group A beta-hemolytic streptococcal infection in patients who have not yet entered adolescence was determined to be a separate disorder. This condition, first defined as PANDAS syndrome (Pediatric autoimmune neuropsychiatric disorders associated with streptococcal infections)

Received: May 07, 2019 Accepted: May 30, 2019 Published online: July 31, 2019

Correspondence: Mehmet Hamdi Örüm, MD. Kahta Devlet Hastanesi, Psikiyatri Polikliniği, 02100 Adıyaman, Turkey. Tel: +90 538 - 2207558 e-mail: mhorum@hotmail.com 
by Swedo et al. ${ }^{[8]}$ According to the National Institute of Mental Health (NIMH), diagnostic criteria of this disease has been determined as presence of obsessive-compulsive disorder (OCD) or tic disorders (TD), disease onset between age three and adolescence, sudden onset of symptoms or accompaniment of dramatic exacerbations, temporal relationship with onset of symptoms or exacerbation and Group A betahemolytic streptococcal infection, and motoric hyperactivity and choreiform movements or tics during exacerbation..$^{[9]}$ In addition to OCD and TD, conditions such as mood disorder, impulse control disorder, and attention deficit hyperactivity disorder (ADHD) is also frequently encountered in these patients. ${ }^{[9]}$ In this case report, the effects of penicillin prophylaxis in two male patients who presented with Tourette syndrome (TS) symptoms with insufficient response to medical treatment were discussed.

\section{CASE REPORT}

Case 1- An eight-year-old male patient followed-up for three years with a diagnosis of Tourette syndrome, with history of risperidone, sodium valproate, methylphenidate, clonidine, and atomoxetine use, presented to our clinic with hyperactivity, inability to remain in place, talking in class, quick boredom, difficulty in peer adjustment, difficulty maintaining relationships, harmful behavior, hand licking, and difficulty writing due to neck and shoulder-shrugging tics. The patient with disobedient, over attached, and defiant behavior at home had no additional history of psychiatric disease and unremarkable family history. The patient was initiated risperidone $0.75 \mathrm{mg} /$ day and methylphenidate $10 \mathrm{mg} /$ day for symptoms and upon improvement the patient continued outpatient follow-up with these doses. Despite medical treatment, similar symptoms suddenly reappeared in March 2018 and increased in severity in a short period of time. Although doses of both drugs were doubled with small increments, symptoms did not improve. The patient's hematologic tests were reevaluated, considering likely upper respiratory tract infection symptoms, anti-streptolysin $\mathrm{O}$ (ASO), C-reactive protein (CRP), and anti-DNase $B$ levels were assessed with significant results leading to consultation with the pediatric health and diseases and initiation of benzathine penicillin G 1.2 million units (milU) intramuscular (IM) prophylaxis. After the third dose, a significant improvement in severity of both TD and ADHD symptoms was observed. Psychiatric drugs were gradually decreased and discontinued. Tic disorders and ADHD symptoms

Table 1. Evaluation of some variables of the cases

\begin{tabular}{|c|c|c|c|c|}
\hline & \multicolumn{2}{|c|}{ Case 1} & \multicolumn{2}{|c|}{ Case 2} \\
\hline & Pre-treatment & Post-treatment & Pre-treatment & Post-treatment \\
\hline ASO (IU/mL) & 412 & 36 & 544 & 68 \\
\hline Anti-DNase B (IU/mL) & 545 & 43 & 495 & 55 \\
\hline \multicolumn{5}{|l|}{ YGTSS } \\
\hline Motor Tics Total score & 20 & 5 & 22 & 6 \\
\hline Phonic (Vocal) Tics Total score & 15 & 0 & 10 & 0 \\
\hline General impairment score & 40 & 10 & 40 & 10 \\
\hline Total score & 75 & 15 & 72 & 16 \\
\hline \multicolumn{5}{|l|}{ Conners parent assessment } \\
\hline Attention deficit & 9 & 5 & 3 & 3 \\
\hline Hyperactivity & 11 & 6 & 10 & 6 \\
\hline Defiance & 10 & 6 & 5 & 5 \\
\hline Behavioral problems & 7 & 7 & 6 & 4 \\
\hline Global health scale & 5 & 2 & 5 & 2 \\
\hline
\end{tabular}

ASO: Anti-Streptolysin O; YGTSS: Yale Global Tic Severity Scale. 
were not observed and functionality returned. Some laboratory and scale data before and after treatment (3 months) is presented in Table 1. Written consent was obtained from the patient's family in order to use the data in scientific studies.

Case 2- An eight-year-old male patient followed-up with diagnosis of Tourette syndrome, characterized predominantly by motor tics especially vocal tics, and with additional ADHD and specific learning disability according to The Diagnostic and Statistical Manual of Mental Disorders Fifth Edition (DSM-V) diagnostic criteria, had persistent symptoms despite sufficient dose and usage period of drugs such as risperidone, methylphenidate, and clonidine was initiated aripiprazole $2.5 \mathrm{mg} /$ day which was increased up to $5 \mathrm{mg} /$ day. At the end of two months, notable reduction in tics was observed. In April 2018, an acute increase in tics and ADHD symptoms was observed. The patient's aripiprazole dose was increased to $10 \mathrm{mg} /$ day, however significant improvement was not observed. While aripiprazole continued at this dose, atomoxetine $10 \mathrm{mg} /$ day and risperidone $0.5 \mathrm{mg} /$ day were initiated. Despite these treatments, no change was observed and the patient's hematologic tests were reevaluated, considering likely upper respiratory tract infection symptoms, ASO, CRP, and anti-DNase B levels were assessed with significant results leading to consultation with the pediatric health and diseases and initiation of benzathine penicillin G 1.2 million units (milU) intramuscular (IM) prophylaxis. After the fourth dose, severity of both TD and ADHD symptoms regressed and ASO and anti-DNase $B$ levels improved. The patient's psychiatric medications were gradually decreased and discontinued. Tic disorders and ADHD symptoms disappeared and functionality returned. Some laboratory and scale data before and after treatment (3 months) is presented in Table 1 . Written consent was obtained from the patient's family in order to use the data in scientific studies.

\section{DISCUSSION}

In this article, effectiveness of penicillin prophylaxis in two patients with exacerbated TD and ADHD symptoms following childhood-stage streptococcus infection was discussed. The fact that onset of disease was associated with infection in both cases surpassed association with PANDAS, however both patients had a prominent and acute increase in symptoms following a probable upper respiratory tract infection in the spring season. Both patients did not benefit from psychiatric treatment. After examining results of biomarkers such as ASO, benzathine penicillin $G$ prophylaxis was initiated and complete improvement in symptoms was observed; psychiatric drugs were discontinued and psychiatric symptoms did not reemerge.

In a portion of OCD and TD patients, symptomatic exacerbation may occur with sudden, dramatic onset sometimes following a period of a few months of well-being. This disease pattern is reminiscent of the course of movements in Sydenham chorea. In addition to choreic movements, many patients with Sydenham chorea have symptoms similar to tics. ${ }^{[10]}$ This was first observed by Osler ${ }^{[1]}$ in 1894 and it was shown that tic symptoms developed following streptococcal pharyngitis by Kiessling et al. ${ }^{[12]}$ in 1993. The knowledge that exacerbation of TD and OCD symptoms following streptococcal infections allows reference to similarity of the course of Sydenham chorea and strengthens the hypothesis that improving immune functions with the help of treatment may be beneficial in TD course with acute symptomatic exacerbations. ${ }^{[8,10]}$ Snider et al. ${ }^{[13]}$ reported that penicillin and azithromycin prophylaxis is beneficial in reducing streptococcal infections and children in the PANDAS subgroup improves neuropsychiatric symptoms.

Symptoms of anxiety, hyperactivity, attention loss, increased academic success, increased motor activity, and restlessness are common in PANDAS cases. These symptoms may persist despite psychostimulant and antidepressant treatments. When there is lack of response to treatment, investigation of biomarkers such as ASO, CRP, and anti-DNase, and emphasis on the interaction between symptomatic exacerbation and state of infection and detailed patient history is believed to be important. In the likelihood of PANDAS, patients do not require psychiatric medication in addition to penicillin treatment and this allows patients to live a more comfortable life. In conclusion, in patients with atypical, fluctuating course, TD symptoms accompanied by OCD and ADHD symptoms, resistant to psychiatric treatment, it should not be forgotten that penicillin treatment may ensure remission in patients. 


\section{Declaration of conflicting interests}

The authors declared no conflicts of interest with respect to the authorship and/or publication of this article.

\section{Funding}

The authors received no financial support for the research and/or authorship of this article.

\section{REFERENCES}

1. Available at: www.who.int/en/news-room/fact-sheets/ detail/mental-disorders.

2. Orum MH, Eğilmez OB. Psychiatric presentation of hypoxic ischemic encephalopathy occurring after a violent suicide attempt: a case of hanging. Dusunen Adam The Journal of Psychiatry and Neurological Sciences 2018;31:228-30.

3. Orum MH, Kuştepe A, Kara MZ, Dumlupınar E, Eğilmez OB, Özen ME, et al. Addiction profiles of patients with substance dependency living in Adiyaman province. Med Science 2018;7:369-72.

4. Orum MH, Kara MZ, Eğilmez OB. Mean platelet volume and neutrophil to lymphocyte ratio as parameters to indicate the severity of suicide attempt. J Immunoassay Immunochem 2018;39:647-59.

5. Özen ME, Orum MH, Kalenderoğlu A. Difficult patient in psychiatry practice: A case-control study. Adıyaman Üni Sağlık Bilimleri Dergisi 2018;4:1064-73.
6. Uysal E, Acar YA, Solak S. A rare cause of personality change in emergency department: Glioblastoma multiforme. Acta Medica Alanya 2017;1:24-7.

7. Kuru T, Türkçapar H. Psychiatric outpatient clinic: A cross sectional study in the context of treatment of schizophrenia. Acta Medica Alanya 2018;2:142-8.

8. Swedo SE, Leonard HL, Garvey M, Mittleman B, Allen AJ, Perlmutter S, et al. Pediatric autoimmune neuropsychiatric disorders associated with streptococcal infections: clinical description of the first 50 cases. Am J Psychiatry 1998;155:264-71.

9. Beşiroğlu L, Ağargün MY, Özbebit Ö, Sözen M, Dilek İ, Güleç M. Streptokok enfeksiyonu ile ilişkili OKB ve tik bozukluğu olan dört olguda plazmaferez tedavisine yanit. Türk Psikiyatri Derg 2007;18:270-6.

10. Allen AJ, Leonard HL, Swedo SE. Case study: a new infection-triggered, autoimmune subtype of pediatric $\mathrm{OCD}$ and Tourette's syndrome. J Am Acad Child Adolesc Psychiatry 1995;34:307-11.

11. Osler W. On chorea and choreijorm alfictions. Philadelphia: HK Lewis; 1894.

12. Kiessling LS, Marcotte AC, Culpepper L. Antineuronal antibodies in movement disorders. Pediatrics 1993;92:39-43.

13. Snider LA, Lougee L, Slattery M, Grant P, Swedo SE. Antibiotic prophylaxis with azithromycin or penicillin for childhood-onset neuropsychiatric disorders. Biol Psychiatry 2005;57:788-92. 